Makale türü / Article type: Araştırma / Research

\title{
Gevaş İlçesinin Kırsal Turizm Potansiyelinin SWOT Analizi ile Değerlendirilmesi
}

$* * * *$

\section{The Evaluation of Gevaş Rural Tourism Potential with SWOT Analysis}

\author{
Doç. Dr. Hilal Surat \\ Artvin Çoruh Üniversitesi, Sanat ve Tasarım Fakültesi, hila1881@artvin.edu.tr \\ ORCID: 0000-0002-2471-8717 \\ Yüksek Peyzaj Mimarı Canan Dinç \\ Van Büyükşehir Belediyesi, canandinc74@gmail.com \\ ORCID: 0000-0002-8708-1936
}

\begin{abstract}
Özet
Gevaş ilçesi sahip olduğu doğal, kültürel ve tarihi kaynak değerler bakımından Van ilinin önemli turizm destinayonları arasındadır. Bu çalışmada, Gevaş ilçesinin kırsal turizm potansiyelini ortaya koyabilmek amacıyla SWOT analizi yapılmıştır. SWOT Analizi için konuyla ilgili doğrudan ilişkili 35 kişi ile görüşmeler yapılmıştır. Yapılan görüşmeler 2018 yılı Haziran, Temmuz, Ağustos ve Eylül aylarında gerçekleştirilmiştir. Görüşmelerin sonuçları değerlendirildiğinde Akdamar Kilisesi'nin varlığı, zengin kültürel değerlerin varlığı ve ilçenin Van gölü kıyısında en uzun sahile sahip olması güçlü yönler olarak öne çıkarken yeterli yatırım ve tanıtım çalışmalarının yapılmaması, tarihi değerlerin ve yapıların korunamaması turizme hizmet edebilecek yeterli alt yapı ve tesislerinin olmaması zayıf yönler olarak değerlendirilmiştir. Çalışma alanında turizm yatırımlarının yapılması yönünde yerel halkın gönüllü olması, yerli turist tarafından tanınırlığının artması ve su sporları aktivitelerine imkân tanıması yönünde firsatlar sunarken kış mevsiminin uzun olması ulaşım şartlarını zorlaması, tarihi yerlerde kontrolsüzce yapılan yapılaşma, doğal yapı ve tarihi yapıların tahrip edilmesi de tehdit faktörleri olarak değerlendirilmiştir.
\end{abstract}

Anahtar Kelimeler: Kırsal Turizm, Sürdürülebilirlik, SWOT Analizi, Akdamar, Gevaş

JEL Sinıflandırması: Z32

\begin{abstract}
Gevaş district is among the important tourism destinations of Van province in terms of its natural, cultural and historical resources. In this study, in order to evaluate the rural tourism potential of Gevaş district SWOT analysis. For the SWOT Analysis, interviews were made with 35. The interviews were conducted in June, July, August and September 2018. Considering the results of the interviews, the existence of the Akdamar Church, the existence of rich cultural values and the longest beach of the district on the shore of Lake Van stand out as strengths, while the lack of sufficient investment and promotional activities, the inability to protect historical values and structures, lack of sufficient infrastructure and facilities that can serve tourism evaluated as weaknesses. It is among the strengths of the local people's volunteering to make tourism investments in the district, increasing recognition by local tourists and allowing water sports activities. The transportation conditions that force the long winter season, historical uncontrolled construction, destruction of natural and historical buildings were evaluated as weaknesses and threats.
\end{abstract}

Keywords: Rural Tourism, Sustainability, Swot Analysis, Akdamar, Gevaş

JEL Classification: Z32

\section{GİRIŞ}

Bölgesel kalkınmada önemli bir rolü olduğu kabul edilen turizmin, özellikle de gelişmekte olan ülkelerin, bölgelerin, yörelerin sahip oldukları turistik potansiyellerinin gelişmelerine ve kalkınmalarına katkı sağlama aşamalarına hız verici etkileri artık iyice anlaşılmıştır (Fabac \& Zver, 2011; Seryasat vd.,2013). Bu yörelerin sahip olduğu doğal ve kültürel kaynakları sayesinde hem bu yöreler turistik yönden kalkınacak imkân ve olanaklara sahip olacak hem de ülke ekonomisine katk1 sağlayabilecekler. Bu nedenledir ki 
endüstriyel gelişmeye uygun olmayan ülkelerde, bölgelerde, yörelerde turizmin bir ekonomik faaliyet olarak geliştirilmesi ile ülkenin, bölgenin ya da yörenin kaynak zenginliğinin refah düzeyinin yükselmesine yardımcı olması yanı sıra, yeni iş imkânları yaratması suretiyle bölgelerarası gelir dağılımında olumlu etki yaparak bütünde dengeli kalkınmaya imkân sağlamaktadır. Aynı zamanda turizm faaliyetleri sebebiyle; gelen turistleri memnun edebilmek amacı ile yapılan elektrik, su, alışveriş ve eğlence merkezleri vb. alt yapı hizmetlerinin, kitle ulaştırma sistemlerinin ve alt yapı hizmetlerinin yüksek standartlara ulaşılması yönünde çalışmaların öncelikli olması ülke ya da bölge halkına da yüksek standartlara sahip hizmetler sağlanmış olacaktır. Bu durum bölgede ekonomik yapının çeşitlenmesine ve yeni endüstrilerin doğmasına ve gelişmesine imkân sağlamış olacaktır. Bütün bu olumlu gelişmelerin yerel dinamikleri doğrudan etkileyeceği, bölgesel ve yerel kalkınma, yeni şartlar ve fırsatlar yaratma açısından yöresel, bölgesel ve hatta ülke boyutta turizm potansiyelini arttıracağı unutulmamalıdır (Barutçugil, 1982; Yeşiltaş \& Öztürk, 2008; Dinçer, 2010; Surat, 2011).

Teknolojide, yaşam biçimlerinde ve düşüncelerde meydana gelen değişmeler sonucu ihtiyaç duydukları ürünlerde ve beklentilerde çeşitlendirme yapılması zorunluluğunu ortaya çıkmıştır. Değiş̧en seyahat amaçlarına paralel olarak insanların 3E (eğlence, eğitim, heyecan) olarak adlandırılan alternatif turizm şekillerine doğru yöneldiği görülmektedir. Bu değişim doğrultusunda tüketici durumlarında ki farklılaşma, öğrenme isteği gibi faktörlerden dolayı turizm talebi de farklılaşmış, daha farklı turizm aktivitelerine katılmak yönünde yoğun bir talep oluşmaya başlamıştır. Bu talep doğrultusunda ortaya çıkan turizm çeşitlerin ayrımında, turizm çeşitlerinin turizmin fonksiyonlarına bağlı olarak şekillenmesinde kişinin turizm faaliyetine katılma sebebi ve önceliği önemli olmuştur (Surat, 2011).

Dünya turizm pazarı, turist profilinde meydana gelen değişimler sonucu ortaya çıkan yeni talep özelliklerine uygun yatırımdan pazarlamaya, işletmeye kadar her alanda yeni stratejiler geliştirmeye ve etkin bir şekilde uygulamaya yönelmektedir. Turizm çeşitlendirmede turizmin kendi iç dinamiği önemli bir faktördür. Kişi hangi sebebin etkisi ile seyahate karar vermişse, buna uygun turizm çeşidi kendini göstermiştir (Toskay, 1989). Öncelikle ülkenin yatırım politikalarını yeniden gözden geçirmek ve değişen turist profiline uygun alternatif turizm çeşitlerinin geliştirilebilmek yönünde adımlar atılmalıdır. Bu adımların başında alternatif turizm ürünleri geliştirmek gelmelidir. Bu sebepledir ki alternatif turizm ürünleri geliştirirken turizm ürünlerinin ve turizm değerlerinin korunarak gelecek nesillere aktarılmasının önemli olduğu yönünde yaklaşımlar benimsenmiştir (Orhan, 2008).

Turizm faaliyetleri doğal, tarihi ve kültürel kaynaklara bağlı olarak gerçekleştirilen faaliyetlerdir. Fakat doğal, tarihi ve kültürel alt yapının tahrip edildiği alanlarda turizmin geleceğinden söz edilemez. Fakat yapılan turizm faaliyetlerinin olumlu etkilerinin yanı sıra ortaya çıkan olumsuz etkiler sonucu ekonomik kalkınma ve doğal kültürel kaynakların etkin kullanım gerekliliğini ortaya çıkmıştır. Unutulmamalıdır ki dünyada her yıl ülke ekonomileri büyüyebilir ancak ekosistem büyümemekte ve bu gelişmeler karşısında ciddi ölçüde zarar görmektedir. Bu açıdan sürdürülebilirlik kavramı turizm sektörü için önem arz etmektedir (Erdoğan, 2005; Akşit, 2007).

Sürdürülebilir turizm anlayışı, gelecek oluşturma adına yeni firsatlar sunarken, beklenti ve gereksinimleri karşılarken, kültürel değişim, biyolojik çeşitlilik ve yaşamsal faaliyetler desteklenirken, ekonomik ve sosyal gereksinimlerin karşılanabileceği yollarda tüm kaynakların planlanıp ve yönetilmesi olarak karşımıza çıkmaktadır (Yücel, 2002; Kahraman \& Türkay, 2004; Uçkun \& Türkay, 2004).

Sürdürülebilir turizm yaklaşımlarının son yıllarda hızlı şekilde gelişmesinin önemli nedeni nüfusun fazla olduğu şehirlerde, gürültü ve hava kirliliği, gibi çevre sorunları ile birlikte yaşamak durumunda olan ve hizmet sektöründe çalışan insanların, yaşadığı ve çalıştığı ortamlardaki nitelik değişimine gerek duymaları ve bu gereksinimlerin turizm talebine yansıması yeni yaklaşımları gündeme getirmiştir. Yeni yaklaşımların gündeme gelmesinde, kitle turizmin ekonomik etkisinin yeterli düzeyde olmaması, arz ve talep arasındaki 
tutarsızlık; diğer yandan giderek artan yoğunluk, kaynakların aşırı tüketilmesi, çevre üzerinde olumsuz tahribatlar oluşturması, kaliteyi bozması etkili olmuştur (Akşit, 2007).

Turistlerin paylaşım, deneyim ve pozitif yönlü etkileşim sağlayabildiği, doğayı tanıma, doğayı sevme, kültürel hassasiyetin ve koruma bilincinin oluştuğu, deneyimlemeye yönelik düzenlenen etkinlikleri içeren sürdürülebilirlik fikri ile beslenebilen günümüzde klasik turizm anlayışına karşı gelişen ve yeni yaklaşımlar arasında yer alan "Alternatif Turizm türleri", turizm sektörüne giriş yapmıştır (Dowling \& Fennell, 2003).

Alternatif turizm, sosyal ve ekolojik yapıya aykırı olmayan, kitle turizmine göre çevreye duyarlı, çevreye turist baskısının daha az olduğu, turistlerin, işletmecilerin ve yöneticilerin çevre konusunda daha bilinçli olduğu, tüketiminin daha az olduğu, yerel katılımının daha fazla olduğu, yerel ve yerel olmayan girişimcilerin ortak çalıştı̆̆ı, alternatif ulaşım ve seyahat imkânları sunabilen ve tüm alanlarda yerli malzeme kullanılmasına öncelik verme amacını güden, doğrudan sürdürülebilirlik hedefinin olması gibi temel özellik ve karakteristikleri taşıyan bir turizm türü” olarak tanımlanmıştır (Balcı vd., 2003, Uçkun \& Özer, 2003).

Alternatif turizm, macera ve tutkuyu seven kişilerin katılım gösterdiği, monoton, gündelik hayattan farklı deneyimler yaşayabildiği, çok fazla turistlik alt yapısı gerektirmeyen, yapılan etkinliklerin öncesi ve sonrasında bilgi birikimi oluşabilen, belli bir gelir seviyesine sahip kişilerin yapabildiği etkinlikler bütünü olarak tanımlanabilir (Hunter \& Green, 1995). Alternatif turizm kapsamında yapılan turistik faaliyetlerin taşıdığı özellik ve karakteristikler dikkate alındığında öncelikle çevre koruma, ekonomik katkı sağlama ve kırsal kalkınmayı ön planda tutan yaklaşımların benimsendiği turistik faaliyetler arasında kırsal turizm faaliyetleri gelmektedir. (Ahipaşaoğlu \& Çeltek, 2006).

Kırsal turizm, kırsal alanlarda kırsal sanayi yapılarını ayarlamak ve optimize etmek, tarımsal sanayi zincirini genişletmek, kırsal turizm hizmetlerini geliştirmek, tarım dışı istihdamı teşvik etmek, çiftçilerin gelirlerini artırmak ve daha iyi bir ekonomik temel oluşturmak için kırsal alanlardaki turizm kaynaklarını tam olarak kullandığı bir alternatif turizm türüdür. Kısaca kırsal turizm, sosyo ekonomik açıdan kısıtlı olanaklara sahip yörelerde gelişmenin önünü açan alternatif ya da mevcut ekonomik etkinliği tamamlayan bir turizm türüdür (Zhang, 2012).

Son yıllarda kırsal alanlardaki yoksulluğun, refah ve geçim hizmetleri kaynaklarına uygun erişimin olmaması nüfusunun azalması önündeki en önemli faktör olarak karşımıza çıkmaktadır. Kırsal alanlardaki gelir ve refahın iyileştirilmesi için çevresel, ekonomik ve üretim potansiyellerinin optimum kullanımını sağlayacak stratejilerin geliştirilmesi kırsal göçü azaltma hedefine ulaşmada etkili olacaktır. Kırsal alanların sosyo-ekonomik kalkınması, istihdam ve gelirin sağlanması için kırsal turizm yaklaşımının bu alanlar için kırsal kalkınmanın motor gücü olabileceğini söyleyebiliriz (Mahmoudi vd., 2011).

Kırsal turizm etkinlikleri istihdamın artmasına, hizmet sektörünün gelişmesine, tarımsal üretimlerin çeşitlenmesine, kente yakın ormanlık alanların değerlendirilmesine ve korunmasına, kırsal peyzajın korunmasına, küçük yerleşim olan göçün önüne geçmesine, kültürel etkileşimin artmasına, doğa koruma bilincinin gelişmesine, tarihsel dokunun korunmasına, yeni girişim ve fikirlerin gelişmesine büyük katkılar sağlamaktadır. Tüm bu gerekçeler doğrultusunda ekonomik kalkınmada yetersiz kalmış ve turizm potansiyeli açısından zengin bir konuma sahip Van ilinin Gevaş ilçesinin sahip olduğu doğal ve kültürel kaynak değerlerinin kırsal turizm bakış açısına yönelik potansiyelinin ve bu mevcut potansiyelin doğal ve kültürel çevreye zarar vermeyecek ve ekonomik faydalar üretebilecek stratejilerin belirlenebilmesi için yerel halk için istihdam imkânlarının oluşturulmasına yönelik imkânların ortaya konduğu, ilçenin daha çok tanıtımına olanak sağlayan, kaynakların korunması ve sürdürebilirliklerinin ön planda tutulduğu turizm planlaması için ön bir çalışma yapılmıştır. 


\section{MATERYAL ve YÖNTEM}

Gevaş ilçesinin sahip olduğu kültürel ve doğal özellikler araştırma materyalini oluşturmaktadır. Gevaş ilçesinin doğal ve kültürel turizm değerleri ile kırsal turizm potansiyelini belirlemek üzere hazırlanan SWOT Analiz anket formaları araştırmanın diğer materyallerini oluşturmaktadır.

Çalışmada "Gevaş ilçesi ve yakın çevresinin doğal ve kültürel turizm değerlerini belirleyebilmek ve ilçenin güçlü ve zayıf yönler ile karşı karşıya bulunan firsatlar ve tehdit unsurlarının ortaya konduğu "mevcut durum" analizi ve aynı zamanda gelecekte oluşabilecek durumların tespit ve tahmin etmeye yarayan "gelecek durum" analizi olarak adlandırılan yakını ve uzağı görmeyi sağlayan bir gözlük olarak tanımlanan SWOT Analizi kullanılmıştır.

SWOT yöntemi bir alanın kaynak değerlerinin kullanımına yönelik planlama yapabilmek, stratejiler üretebilmek, alanları ve kullanımları organize etmek amacıyla kullanılan bir araçtır (Kazemiyeh, 2016). Çalışmada kullanılan SWOT Analiz Tekniği potansiyel ve mevcut turizm faaliyetlerini belirleyip ve bunların planlaması, sürdürülebilirliği için çeşitli rasyonel yaklaşımlarda bulunmasına yardımcı olabilen, çalışma ile ilgili mevcut güçlü yanlar (avantajlar) ve zayıf yanlar (dezavantajlar) ile birlikte gelecekte oluşabilecek firsatlar ve tehditler önceden tespitinin yapılabildiği planlama ve yönetim aşamasında karar vermede kullanılan bir araştırma tekniğidir (Gürlek, 2002; Polat 2006).

İlçenin güçlü-zayıf yönleri ile yapılan ya da yapılacak faaliyetler sonucu ortaya çıkan firsat ve tehdit unsurlarını belirleyebilmek için konuyla ilgili doğrudan ilişkili olan 15 Akademisyen, Gevaş Belediyesinde çalışan yetkili 5 kamu personeli, Gevaş Kültür İşleri Müdürlüğünde çalışan yetkili 5 kamu personeli, turizm sektöründe hizmet veren 10 işletme sahibi olmak üzere toplam 35 kişi ile görüşmeler yapılmıştır. Yapılan görüşmeler 2018 yılı Haziran, Temmuz, Ağustos ve Eylül aylarında gerçekleştirilmiştir. Görüşmelerde ilgili kişilere ilçe ve yakın çevresinin turizm potansiyelini oluşturan mevcut kaynak değerlerinin neler olduğunu belirlemeye yönelik görüşleri sorulmuştur. Ayrıca katılımcılara ilçenin sahip olduğu ve turizm açısından güçlü olduğu yönleri, sunduğu firsatları, ilçenin zayıf yönlerini, aynı zamanda yapılan ve yapılabilecek turistik faaliyetler için ortaya çıkan/çıkabilecek tehdit unsurlarının neler olduğuna yönelik görüşleri sorulmuştur.

\subsection{Araştırma Alanının Doğal ve Kültürrel Özellikleri}

Araştırma sahasında bulunan İlçe Van ilinin güneybatısında yer almaktadır. İlçenin yüz ölçümü ise 727,5 $\mathrm{km}^{2}$ dir. İl merkezine uzaklığ $40 \mathrm{~km}$. dir. Gevaş ilçesi Artos Dağ 1 veya Çadır Dağı olarak da bilinen (3650 m.) eteğinde kurulmuştur (Şekil 1).

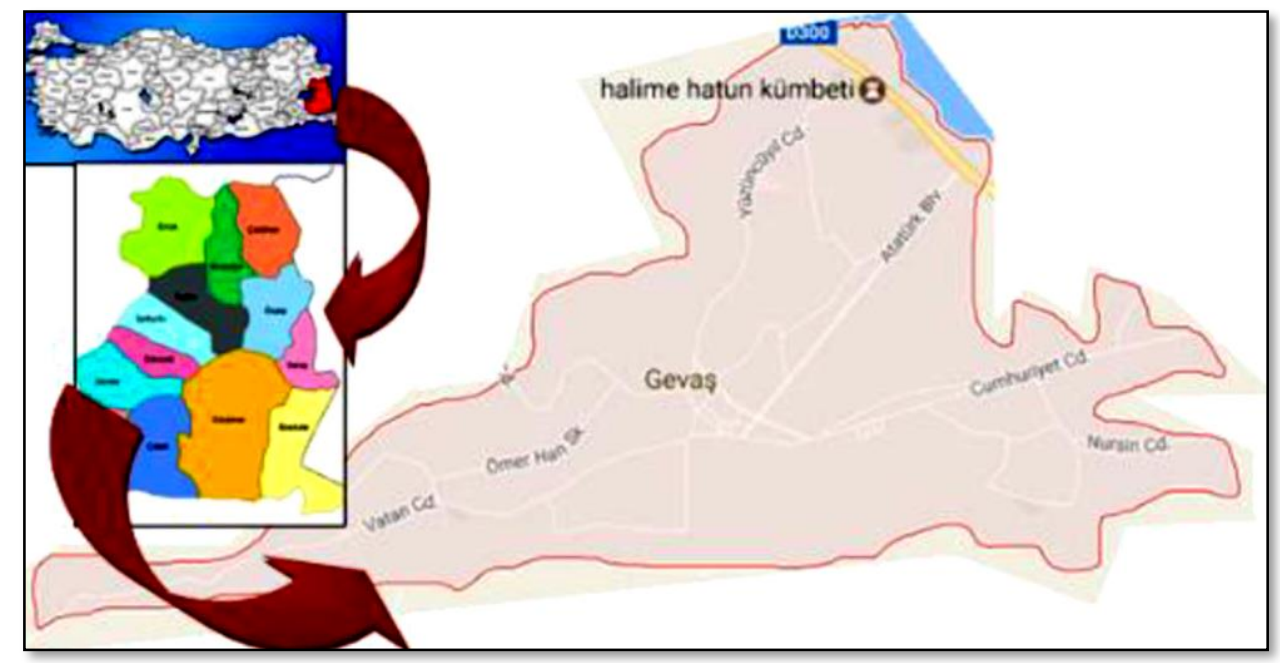

Şekil 1. Çalışma alanı 
Gevaş'ın doğuda Gürpınar ilçesi, batıda Hizan (Bitlis) ve Tatvan (Bitlis) İlçeleri mevcut, kuzeyinde ise Van Gölü, kuzeydoğusunda Edremit, güneyinde ise Çatak, güneybatısında Bahçesaray ilçeleri mevcuttur. Araştırma sınırlarında yer alan Gevaş İlçesine bağlı Abalı Aladüz, Altınsaç, Aydınocak, Bağlama, Dağyöre, Daldere, Değirmitaş, Dilmetaş, Dokuzağaç, Göründü, Gündoğan, Hasbey, İkizler, İnköy, Kayalar, Kazanç, Kızıltaş, Koçak, Kurultu, Kuşluk, Timar, Töreli, Uğurveren, Yanıkçay, Yemişlik, Yoldöndü ve Yuva köyleri bulunmaktadır (http://nasilbiryer.net, 01.07.2019). İlçede bulunan en önemli akarsu olan ve aynı zamanda Van Gölüne dökülen Hoşap Suyudur.

Tarihi Değeri İlçenin tarihi M.Ö 5 bin yılları arasına dayanmaktadır. M.Ö 89. yy yılları arasında Urartuların buraya geldiği ve aynı zamanda M.Ö. 5.000 yıllarında Sümerlerin de buraya gelip ve buradan da Mezopotamya'ya göç ettiği, aynı yüz yılları arasında Mete istilasına uğradığı ve daha sonra Pers İmparatoru döneminde kurulmuş medeniyetin izlerini taşımaktadır. İlçe Malazgirt Zaferi ile Türk topraklarına dahil olmuş. Van iline bağlı olarak varlığını devam etmiştir ve 1927 yılında şimdiki mevcut yerinde olan geniş bir araziye kurulmuştur (https://www.arkeolojikhaber.com, 05.07.2019).

Bir bölgede yer alan doğal bitki örtüsü bölgenin kalkındırılmasında ve turizm açısından çok önemli bir faktördür. Araştırma alanında doğal koşullar, bitki örtüsü açısından orman için elverişli olmasına rağmen Nemrut Kalderası içindeki huş (Betula pendula), titrek kavak (Populus tremula) gibi ağaçlar ile su boylarındaki kavak ve söğüt ağaçları, İnköyü ve Altınsaç köylerinde ardıç (Juniperus oxycedrus subsp. oxycedrus ve Juniperus excelsa) ve meşe (Oercus robur subsp.pedunculijlora ve Quercus petraea subsp pinnatiloba) vb. türlerin yan isıra Astragalus spp., Centaurea spp., Silene spp. ve Orchis spp. gibi otsu türlere de rastlanılmaktadır. Van'a özgü olan ve aynı zamanda endemik olan ters lale (Firitillaria imperialis) ve birinci dereceden sit alan olarak ilan edilen Akdamar Adasının üzerinde mevcut olan badem ağaçları (Prunus dulcis) bahar mevsiminde ada ve çevresinde görsel şölen oluşturmaktadır (Şekil 2) (Bingöl, 2004).

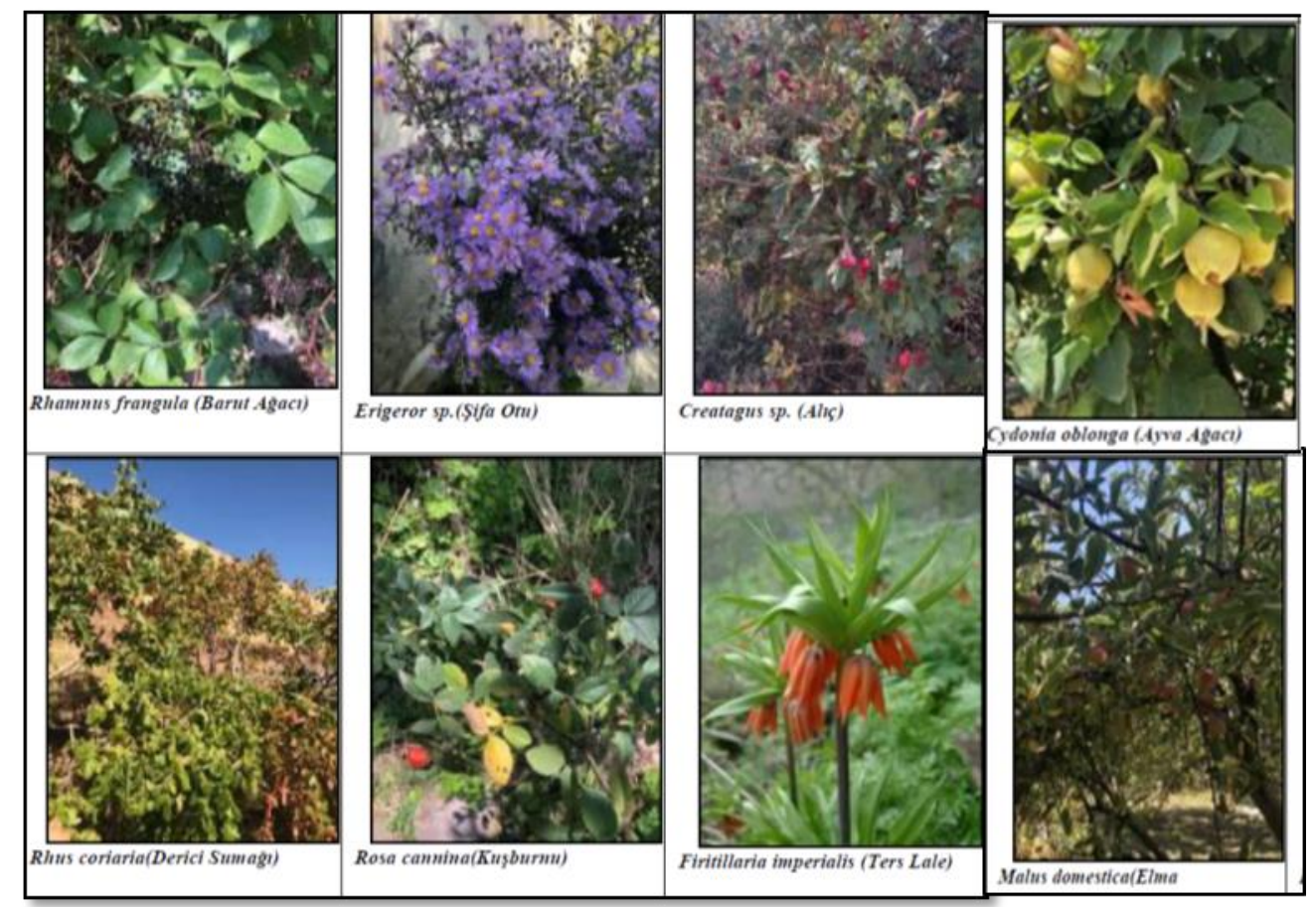

Şekil 2. Çalışma alanında peyzaj değeri olan bitki türlerinden görseller

İlçe ve yakın çevresi av hayvanları ve yaban hayatı bakımından zengin bir potansiyele sahiptir. Dağlık arazilerde bulunan tavşan, tilki, dağ keçisi, ayı gibi hayvanlara çok sık rastlanırken kuş çeşitleri sayıca olarak çok fazladır. Dikkuyruk (Oxyura leucocephala), Uludoğan (Falco cherrug), kışın Ötücü kuğu (Cygnus cygnus) alanda yaşayan türler ve nesilleri alanda tehlike altındadır. Van Gölü martısı (Larus 
armenicus), Küçük kerkenez (Falco naumanni), Küçük akbaba (Neophron percnopterus) ve Kaya kartalı (Aquilla chrysaetos) sahada çok sık görülen türlerdir. Aynı zamanda alanda çok sayıda yaban ördeklerine ve kazlara farklı mevsim aralılarında rastlamak söz konusudur (Durmuş \& Adızel, 2014).

Artos Dağı, görüntüsü itibarıyla aynı zamanda Çadır Dağı olarak da bilinmektedir. Van Gölünün sayesinde oluşan mikro klima sayesinde Artos dağının güney ve kuzey yüzü arasında iklim açısından önemli derecede fark mevcuttur (Alaeddinoğlu, 2006). Artos (Çadır) Dağı çok soğuk ve sert rüzgârlara rağmen alanın iklimini önemli derecede yumuşatmaktadır. Doğa sporları, volkanik özelliği ile flora ve faunasıyla bilim adamlarınca çok önemli olarak da görülmektedir. Dünyada Artos dağına aynı özellikleri taşıyan dağ Yeni Zelanda'da bulunmaktadır. (Çiftçi vd., 2008). İnköy ve Altınsaç bölgeleri dağlık ve kayalık alanlar olduğundan dolayı, bu yerlere karayollarıyla ulaşım sağlamak mümkün fakat zor ve zaman alıcı olmaktadır. Tekne kullanılmasıyla daha rahat şekilde ulaşım sağlamak mümkün olmaktadır. (Çiftçi vd., 2008).

Yöre ve yakın çevresinde Ortaçağ ve sonrası inşa edilen birçok tarihi ve mimari yapıların başında dini yapılar mevcuttur. Bölgenin tarihi geçmişi Eskiçağ dönemine kadar gitmektedir. Aynı zamanda farklı İslam ve Türk devletlerinin alanda oluşturmuş oldukları tarihi kalıntı ve miraslar, bölgede kültürel canlılığın üst düzeyde olduğunun bir göstermektedir. Hıristiyan Ermenilerin yaptığı dini eserler arasında ise mabet ve manastır kuruluşları hem mimari hem de süslemeler ile ön plandadır. İlçede Selçuklulardan kalma bölgenin ikinci büyük mezarlığı olan ve 400'den fazla mezarı içinde barındıran Selçuklu Mezarlığı vardır. Bu mezarlı̆̆ın yanı sıra Urartular devrinde yapılmış ve sonradan Selçuklular zamanında kullanılmış olan Selçuklu taş ve oyma sanatı kendine has yapısını süsleme ve hat sanatının en güzel örneklerinden olan Halime Hatun Kümbeti ilçede bulunmaktadır (Şekil 3) (Baş \& Gül, 2018).

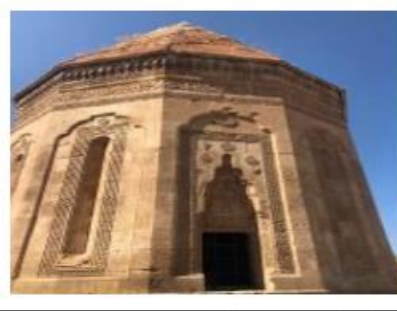

Halime Hatun Kümbeti ve

Selçuklu Mezarlığı

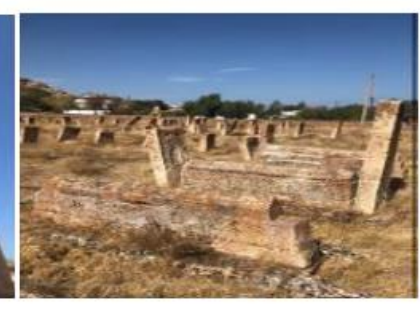

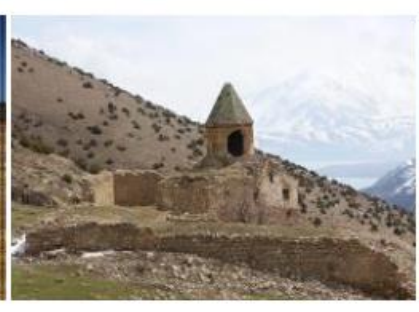

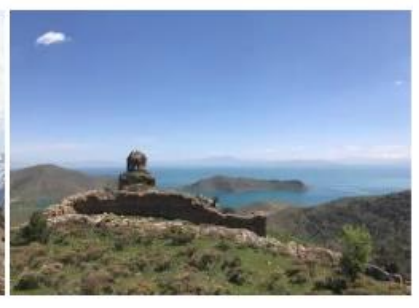

Göründü Kırmızı Kilisesi ve Thomas Manastırı Altınsaç Kilisesi

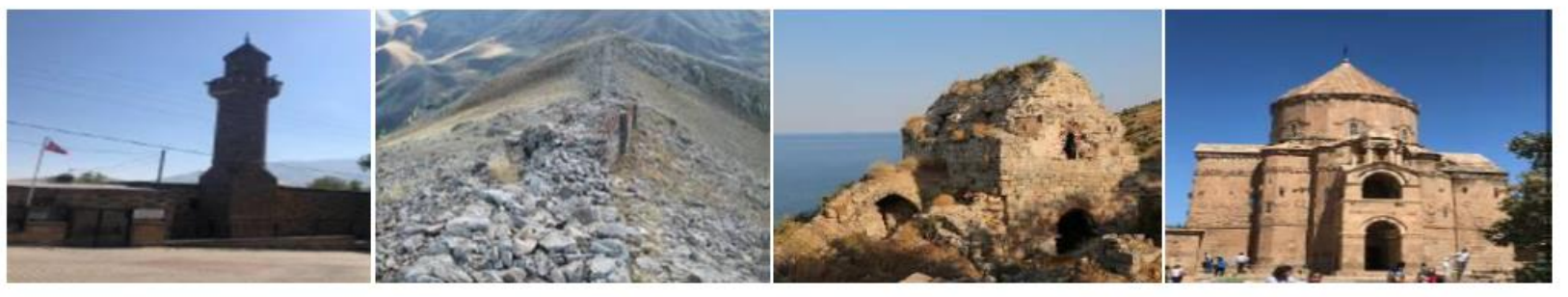

İzzetin Şir Camisi ve Gelengeh Kalesi

Deveboynu Manastırı ve Akdamar Kilisesi

Şekil 3. Gevaş ve yakın çevresindeki tarihi ve dini yapılardan görseller (Fotoğraflar: Dağıstan Deniz)

Turizm değerleri kültürel ve doğal değerler olarak ikiye ayrılmaktadır. Doğal değerler topografya, iklim, hidroloji, yaban hayatı, vejetasyon, konum şeklinde alt sınıflara ayrılabilir. Kültürel değerler ise, tarih öncesi kalıntılar, tarihi mekânlar veya fuar, panayır, folklorik törenler şeklinde oluşmaktadır (Weaver \& Opperman, 2000). Turizm bakımından doğa bir çekim kaynağı olarak işlev görmüştür. Kültürel değerlerin, tüketimden çok keşfi gerektiren çekicilikleri, kırsal turizm bakımından önem arz etmektedir. Bu yönden çalışma alanın doğal ve sosyoekonomik yapısı ve kültürel özellikleri çalışma kapsamında incelenmiş ve mevcut turizm değerleri (Tablo 1) ve ilçede yapılan ve yapılabilecek turizm etkinlikleri ve alanları (Tablo 2) 'de ortaya konmaya çalışılmıştır. 
Tablo 1. Gevaş İlçesinin Turizm Çekicilikleri

\begin{tabular}{|c|c|}
\hline Doğal Çekicilikler & Tarihi ve Kültürel Çekicilikler \\
\hline 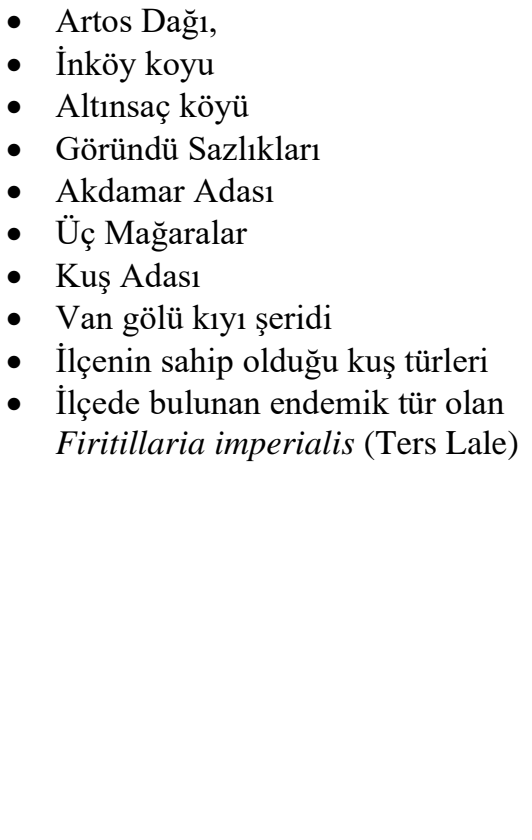 & $\begin{array}{ll}\text { - } & \text { Akdamar Adası Kilisesi } \\
\text { - } & \text { İzettin Şir Camisi, } \\
\text { - } & \text { Halime Hatun ve Selçuklu Mezarlığı, } \\
\text { - } & \text { Kırmızı Kilise, } \\
\text { - } & \text { Ağin Mezrası Deveboynu Mevkii Kilisesi, Altınsaç Köy İçi Kilisesi } \\
& \text { ve Manastırı (Surp Thomas Manastırı), } \\
\text { - } & \text { Altınsaç Varis Mezrası Mevkii Kilisesi, Hasbey Şapeli } \\
\text { - } & \text { Göründü Manastırı } \\
\text { - } & \text { Kuşadası ve manastırı } \\
\text { - } & \text { Varis Bölgesi Ermeni Yerleşimi (sadece kalıntılar var/ulaşım zor) } \\
\text { - } & \text { Dilmetaş islam mezarlığı } \\
\text { - } & \text { Gelengeh kalesi } \\
\text { - } & \text { Bağlama kilisesi } \\
\text { - } & \text { Üç mağaralar } \\
\text { - } & \text { Artos Doğa ve Kültür Festivali, } \\
\text { - } & \text { Akdamar Çocuk ve Gençlik Tiyatroları Şenliği, } \\
\text { - } & \text { Gevaş Turizm Festivali } \\
\text { - } & \text { Bisiklet Festivali } \\
\text { - } & \text { Girgırani, Tekayak, Koçeri, oyunları } \\
\text { - } & \text { Keledos yemeği, cılbır, pişirok, helis en önemli yöresel yemekleri }\end{array}$ \\
\hline
\end{tabular}

\section{2. İlçenin Turizm Potansiyeli Açısından Mevcut Durumu}

Van ili Gevaş ilçesinde bulunan Akdamar Kilisesi, Ortodokslarca çok önemli kabul gören, en önemli Hıristiyan inancı mabedi olarak bilinmektedir. Aynı zamanda her yıl düzenli olarak Eylül ayında ayinler düzenlenmektedir.

$>\quad$ Akdamar Adası, hem üzerinde bulunan ve her yıl yüzlerce turistin ziyaret ettiği Akdamar kilisesi hem de doğal yapısı ile önemli bir turizm değeri taşımaktadır.

> Gevaş ilçesi, kültürel ve arkeolojik değerler açısından zengin olup, Urartu medeniyetine ev sahipliği yapmış ve halen bu medeniyetin izlerini taşıyan birçok tarihi eseri barındırmaktadır.

İlçenin de sınır olduğu Van Gölü ve kıyısında bulunan birçok sahil, ilçede turistik faaliyetlerin geliştirilmesi için önemli bir potansiyel oluşturmaktadır. Özellikle ilçeye bağlı İn Mahallesi’ndeki Ağin, Altınsaç ve Deveboynu koyları ve kamp alanlarının bulunması yaz ayları boyunca yoğun bir kullanıcı faaliyetinin olmasına neden olmaktadır. Özellikle yerli halka hizmet veren bu kıyılar Temmuz-Ağustos aylarında ve hafta sonlarında rekreasyon amaçlı yoğun olarak kullanılmaktadırlar.

Gevaşta çayın kıyılarında oluşmuş sazlıklarda Bolboschoenus maritimus var. maritimus, Typha latifolia, Phragmites australis, Schoenoplectus lacustris subsp. tabernaemontani, Sparganium erectum subsp. erectum ve S. erectum subsp. microcarpum vb. bitki türleri mevcuttur. Özellikle göç dönemlerinde alanın ornitolojik zenginliği artmaktadır. Nesli dünya çapında tükenme tehlikesi altında olan ve alanda üreyen Dikkuyruk ördeği (Akbaş) (Oxyura leucocephala) ilkbahar'da alanda görmek mümkündür. Böylelikle göç zamanında kuşların toplanma alanlardan biri olması alanın değerini arttırmaktadır.

$>\quad$ Gevaş’ta bulunan Göründü Köyü Sulak Alanı, Akdamar Adası'nın güneybatısında, Van Gölü'nün güney kıyısında yer almaktadır. Yerleşim yerlerinden uzak mesafede bulunması nedeniyle bu sazlığın doğal yapısı korunmuştur. Alanın su varlığı ve mevcut bitki örtüsü, sunduğu manzara imkanları ve sahip olduğu doğal yapısı ile görsel peyzaj değeri yüksek bir alandır. Bu alanda; kuş gözlemciliği, doğa yürüyüşü ve foto safari gibi etkinliklerin yapılabileceği yüksek bir potansiyele sahiptir. 
Akdamar adası yakınında bulunan kuş adası da üzerinde bulunan kilise si ile görsel olarak peyzaj değeri yüksek manzaralar sunmaktadır.

> İlçede bulunan Artos Dağı ve çevresindeki trekking faaliyetleri aktif olarak gerçekleştirilmektedir. Ayrıca bu alanlarda kaya tırmanışları da yapılmaktadır.

$>\quad$ İlçede turizme kazandırılacak köyler ve bu köylerde konaklamayı sağlayabilecek, ev pansiyonculuğu için kullanılabilecek yöresel evler bulunmaktadır.

Van Gölü'ne kıyısı olan ilçe ve yakın çevresi su sporları açısından önemli bir avantaja sahiptir. Özellikle İnköy koyu ve Altınsaç köyü kıyı sahili su sporları ve kamp aktiviteleri için uygun bir potansiyele sahiptir.

$>\quad$ İlçede doğal olarak yetişen aynı zamanda endemik bir tür olan Firitillaria imperialis (Ters Lale) kendine özgü görüntüsü ve özelliği ile flora turizm değeri açısından ön plana çıkmaktadır.

$>\quad$ Dini inançlar, turizm hareketlerinin hızlandırmada çok önemli bir potansiyel oluşturmaktadır. Birçok uygarlığı içeren, Hıristiyanlık, Yahudilik ve İslamiyet dinsel kimliklerin izlerini taşıyan Gevaş ilçesi, iz bırakmış birçok mekânlar bulunmakla beraber bu özelliği ile yerli halk ve yabancı ziyaretçilerin ilgi odağı olmuştur. Özellikle Van'a gelen yerli ve yabancı turistlerin ilk olarak tercih ettikleri yer Akdamar Adası ve Kilisesidir.

$>\quad$ Hem ulusal hem de uluslararası pazarda kendine has olarak bilinen ve kabul gören bir mutfağa sahip olan Van ve tüm ilçelerinde, gelen ziyaretçiler için en üst düzeyde zevk almalarına olanak sağlayan turistik bir deneyim haline getirilebilecek yeme içme festivalleri gerçekleştirilebilecek bir potansiyel mevcuttur.

> İlçe sınırları içerisinde bulunan Varis Bölgesi Ermeni Yerleşimine ait izleri taşıyan kalıntılar bulunmaktadır. Aynı şekilde Tatvan yolu üzerinde bulunan Gelengeh Kalesi de büyük bir kısmı yıkılmış olsa da halen kalıntıları bulunmaktadır. Fakat ulaşım zorluğu nedeniyle bu iki alan bakımsızlıktan kaderlerine terk edilmiştir.

$>\quad$ Eski çağlardan beri yerleşmeye sahne olmuş olan ilçe ve yakın çevresi, kültürel zenginliğini her alanda hissettirmiştir. İlçe ve yakın çevresinde kurulan medeniyetlerin etkisiyle bu coğrafi avantaj ilçeye birçok zengin yöresel el sanatları ve çeşitliliği kazandırmıştır. Turizm açısından önemli olan el sanatlarının başında, halı ve kilim dokumacılığı, gümüş ve bakır işletmeciliği, el işlemeleri, toprak ev eşyaları, yöresel kıyafetler gelmektedir. Aynı zamanda Urartulardan kalma halı kilim dokumacılığı önemli bir potansiyele ve ulusal pazara sahiptir.

İlçenin, inanç turizmi için önemli bir potansiyel taşıyan Akdamar Kilisesi, kamp ve suya dayalı rekreasyonel faaliyetlerin yapılabileceği Van gölüne kıyısı olan İnköy ve Altınsaç yerleşim alanları, doğa yürüyüşü, yamaç paraşütü, kelebek gözlemciliğinin yapılabileceği Artos Dağ 1 ve etekleri, tarihi ve kültürel yapıları ziyaret edebilecekleri Halime Hatun Türbesi, İzzettin Şiir Camisi ve Selçuklu Mezarlığı, kuş gözlemciliği yapılabilecek Akdamar adası, Göründü sazlıkları önemli turizm değerleri arasındadır. Ayrıca her yıl düzenlenen bisiklet ve Artos doğa ve kültür festivali de önemli ziyaretçi potansiyeli olan turizm faaliyetleri arasındadır. Altınsaç Bölgesi ve Hişet Kalesi çevresi güzel görsel görüntüler sunan manzara seyir alanları olarak değerlendirilebilecek yüksek potansiyele sahip alanlardır. Akdamar Adası ve Kuş Adası Manastırı aynı zamanda görsel su manzaraları ve panoramik manzaralar sunmaktadır. İlçede; dinitarihi ve kültürel yapıları ziyaret etmek, festival, şenliklere katılmak, doğa yürüyüşü (sportif amaçlı keşif amaçlı) dağ tırmanışı yapmak, kamp yapmak, yamaç paraşütü yapmak, flora keşfi, kuş-kelebek gözlemciliği, foto safari, bisiklet safari gibi etkinliklerin rahatlıkla yapılabilecek bir turizm potansiyeli olduğu görülmüştür. 
Tablo 2. Araştırma alanındaki potansiyel turizm etkinlikleri

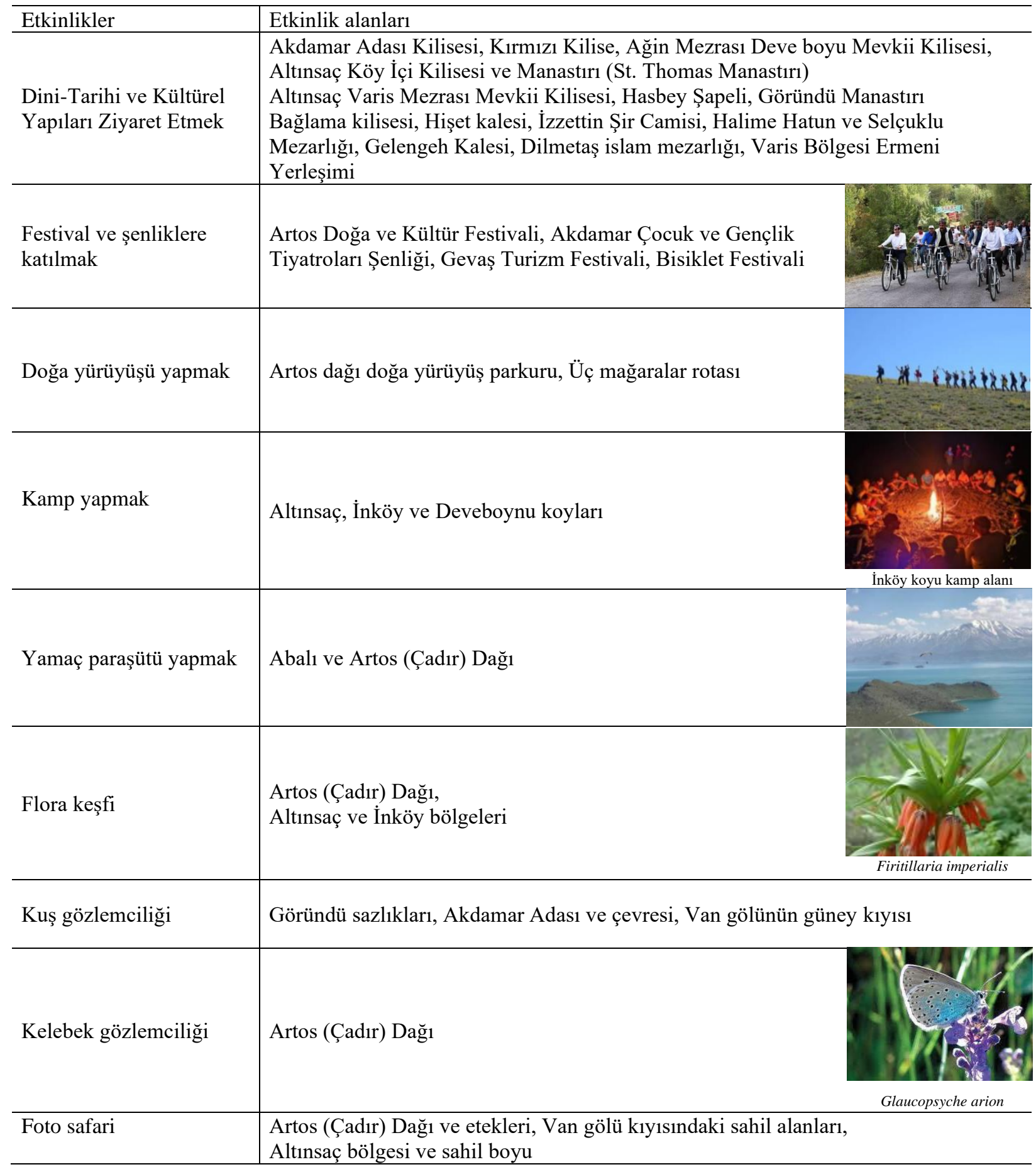

\section{BULGULAR ve TARTIŞMA}

\subsection{SWOT Analizi ve Değerlendirmeleri}

Çalışma kapsamında yapılan SWOT Analizi sonucu aşağıdaki tablo 3'de verilmiş olup, bu çıkan sonuçlar doğrultusunda çözüm önerileri getirilmiştir. Gevaş ilçesi ve yakın çevresi için yapılan SWOT analizi değerlendirme sonuçları aşağıda Tablo 3'de verilmiştir. 
Tablo 3. Çalışma alanın mevcut durumunu ortaya koyan SWOT analizi değerlendirmesi

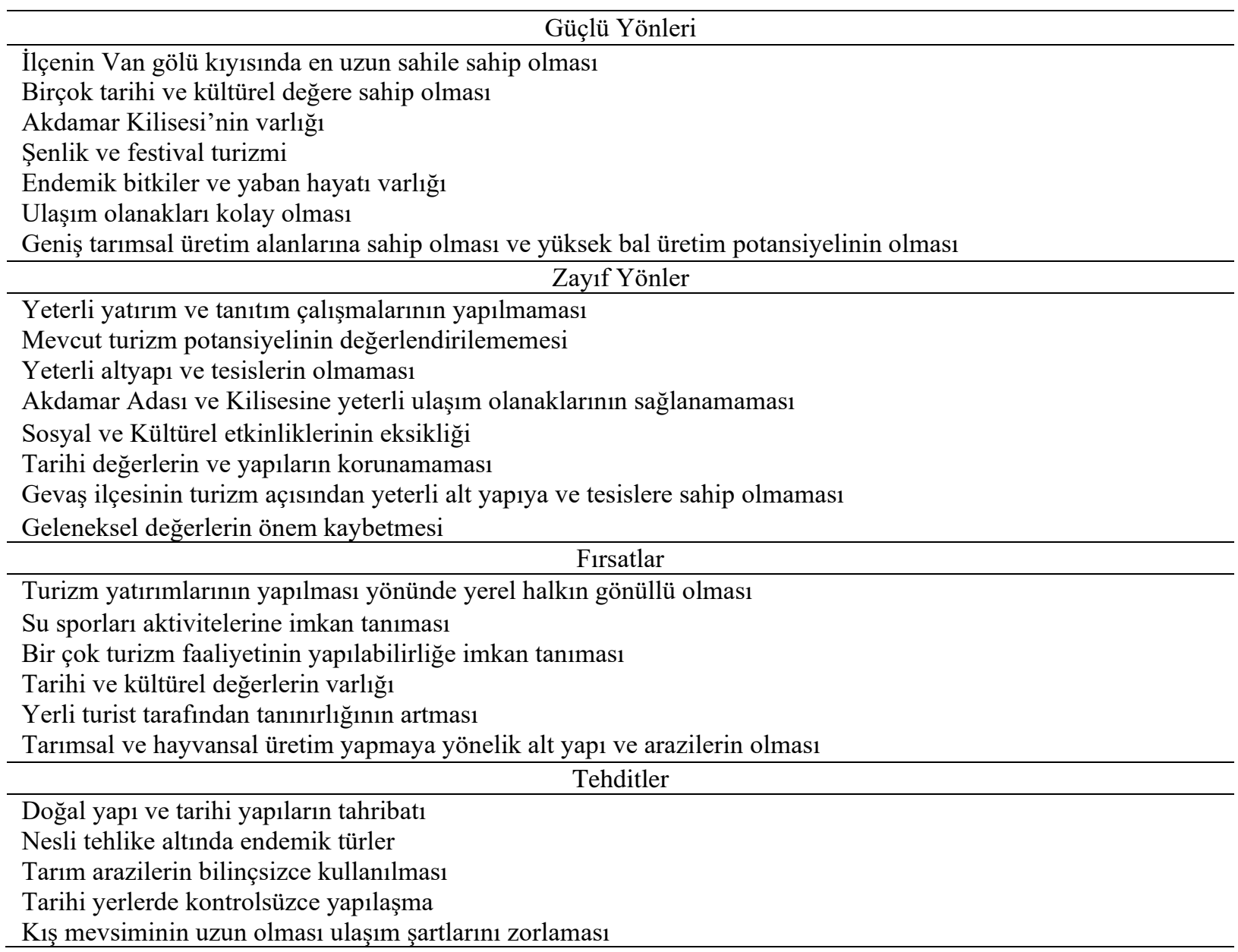

İlçede kırsal turizmin geliştirilebilmesi için öncelikle altyapıya yönelik yapılacak planlama çalışmalarında yer seçimi, ulaşım, konaklama, kirlilik, doğal alanların ve su alanlarının korunması, mevcut yapının korunmasına yönelik düzenlemelere önem verilmelidir. Doğal değerlerin sürekliliğinin sağlanabilmesi için, yapılacak faaliyetler sonucu oluşacak çevre kirliliği alınacak tedbirler sayesinde kontrol altında tutulabilir. Avcıkurt vd. (2009)'e göre kırsal kalkınmada, bölgeler arası dengesizliklerin giderilmesinde ve gelişmenin sağlanmasında turizm potansiyeli önemli rol oynamaktadır Yapılan araştırma da; Gevaş İlçe Merkezi, Akdamar adası, Altınsaç, İnköyü, Göründü köyleri gerek sahip oldukları doğal güzellikleri gerekse kültürel varlık değerleri ile turizm açısından önem arz etmektedirler. Surat (2015) turizm faaliyetlerine doğal, tarihi ve kültürel varlıkların çekicilik özellikleri yön verdiğini vurgulamıştır.

İlçe ve yakın çevresinde çeşitli turizm aktiviteleri uzun yıllardır devam etmektedir. Fakat söz konusu turizm aktiviteleri bilinçli olarak kırsal turizm amaçlı olarak yapılmasa da bu alanlarda yapılan etkinliklerin tümü kırsal turizm etkinlikleri olarak tanımlanabilir. İlçede; doğa yürüyüşleri, dağ tırmanışları, yamaç paraşütü, kamp etkinlikleri, bisiklet safariler, dini amaçlı yapılan ziyaretler vb. gibi etkinlikler devam etmektedir. Bu etkinlikler özellikle yaz aylarında daha da artmaktır. Bu etkinliklerin ve bu etkinliklerden kaynaklı yoğunluğun yıl içerisine dağıtılması alanın doğal ve kültürel yapısının bozulmaması adına yapılacak ilk adımlardan biri olacaktır.

İlçenin ekonomik açıdan gelişememesi, refah düzeyinin istenilen düzeyde olmaması, iş imkânlarının yeterli olmaması nedeniyle genç nüfusun azalmıştır. İlçede özellikle kadınların işgücüne katılım oranı yok denecek kadar azdır. Sürdürülebilir turizm kapsamında yerel halkın sürece desteği kaçınılmazdır. Eğer bu destek tek taraflı olarak sağlanmaya çalışırsa ilçenin vermiş olduğu yoğun göçten kaynaklı istihdam edilecek iş 
gücünün eksikliği ortaya çıkmaktadır. Kırsal turizm faaliyetlerine yönelik yapılabilecek yatırım ve teşvikler ile mevcut iş gücü bu sektörlere aktarılarak hem göçün önüne geçilebilinecek hem de hane başına ekonomik kazancın artırılmasına katkı sağlanmış olacaktır. Böylelikle hem ekonomik anlamda hem de kaynakların korunması anlamında sürdürülebilirlik bilinci oluşturulmuş olacaktır. Kazandıkça koruyacaktır...

Yöreyi kırsal turizm açısından ilgi görebilecek bir merkez haline getirebilmek ve ilçe halkına gelir sağlayacak, istihdam yaratacak hizmet ihtiyacını karşılayacak, yol gösterecek bir dizi tedbir alınması önemli bir husustur. Ayrıca alt ve üst yapı yetersizliklerinin doğal çevreyi bozmadan giderilebilmesi, günübirlik konaklama tesislerinin açılabilmesi (pansiyon, çadır-kamping vb.), mevcut tesislerin ve atıl durumlarda bulunan çiftliklerin durumlarının iyileştirilebilmesi için yerel halka teşvik ve kredi verilmesi gibi özendirici tedbirlerin alınması da gerekmektedir.

Yapılacak olan konaklama hizmetlerinde doğal ve kırsal çevre ile uyumlu, geleneksel yapı kültürü ve konut mimarisi göz önünde tutulması gereklidir. Yörede yapılacak konaklama tesislerinde geleneksel sivil mimariye uygun olmayan yatırımlar yerine, daha küçük ölçekli yöresel mimari tarzına uygun, daha doğal materyallerin kullanıldığ ${ }_{1}$ konaklama ünitelerine öncelik verilmelidir. Bu nedenle özellikle kamp yapılabilecek alanlar arasında yer alan İnköy koyu ve Altınsaç kıyı alanında alt yapılarının oluşturulmasına öncelik verilmelidir.

Gevaş kuş gözlemciliği için uygun alanlara sahiptir. Ancak bugüne kadar ilçede kuş gözlemciliği rotaları belirlenmemiş ve yön levhaları konulmamıştır. Göründü köyü sazlıklarında kuş gözlemciliği rotaları belirlenip, işaretlemeler yapılmalı ve yön tabelaları konulmalıdır. Sadece kuş gözlemciliği için rotalar belirlenmeyip ziyarete gelen turistler için de ilçe merkezinde ve çevresinde bulunan tüm doğal, tarihi ve kültürel değerleri görebilecekleri rotalar belirlenip yönlendirme tabelaları konulmalı. Ayrıca belirlenen rotalar sayısal ortama aktarılarak broşür veya harita olarak hazırlanıp seyahat acentelerinin kullanımına da sunulabilir. Akdamar adası ve yakınında bulunan kuş adası yoğun turist ilgisi nedeniyle Akdamar iskelesi yeterli olmamaktadır. Bu ilgi ve talebin karşılanabilmesi için iskele ve taşımacılık sisteminin iyileştirilmesi önerilmektedir.

İlçe sınırları içerisinde bulunan Varis Bölgesi Ermeni Yerleşimine ve Gelengeh Kalesi de kalıntıları ulaşım zorluğu nedeniyle bu iki alan bakımsızlıktan kaderlerine terk edilmiştir, fakat gerekli restorasyon çalışmaları yapıldıktan ve ulaşım ile ilgili alt yapı çalışmaları yapıldıktan sonra bu iki tarihi değere sahip alan ilçe için önemli turizm çekicilikleri arasına girebilecek bir potansiyele sahiptir. Aynı zamanda Göründü Kırmızı Kilisesi, Deveboynu Manastırı ile Altınsaç Kilisesi de restore edildikten sonra ilçe için önemli turizm değerleri arasında yerlerini alacaklardır.

Gevaş’ta kırsal turizm alt yapısı oluşturulurken yerli halkının da görüş ve önerileri göz önünde bulundurulması gerekmektedir. Gevaş ilçesi, Van gölüne en uzun kıyı şeridine sahip olan Gevaş ilçesinde özellikle kıyı şeridinin doğal yapısının bozulmadan konaklama ihtiyacının karşılandığı ve aynı zamanda tekne ve benzeri araçların park edebilecekleri iskelelerin yapılması gerekmektedir. Gevaş'ta yapılacak olan kırsal turizm aktiviteleri için bölgesel rehberler yetiştirilmelidir. Bu rehberler kırsal turizm konusunda uzmanlaşmış kişiler olmalıdır.

Van ili ve Gevaş ilçesinde bulunan kamu kurumları ve sivil toplum örgütleri arasında iletişim eksikliği bulunmaktadır. Her kurum kendi başına diğer kurumlardan habersiz bölgede kırsal turizm ile ilgili bir takım faaliyetler yapmakta, fakat ortaya konulan çalışmaların hiçbiri Gevaş’ın kırsal turizm potansiyelini yeterli düzeyde yansitamamaktadır.

Özellikle yörede geleneksel halk oyunlarının tanıtılması, halı dokumacılı̆̆ı, el işi takı yapma gibi geleneksel ürünlerin devamlılıklarının sağlanması için buna yönelik usta-çırak eğitim kurslarına öncelik verilmeli. Ayrıca ilçenin kendine özgü yöresel ürün çeşitlerinin tanıtılmasına öncelik verilmeli. 


\section{SONUÇ ve ÖNERILLER}

SWOT kullanılarak kırsal turizm planlama stratejilerinin belirlendiği birçok araştırma mevcuttur. Sayyed vd. (2013)'de İran'daki Tandooreh Ulusal Parkında yaptıkları araştırmada SWOT analizini kullanmışlar ve araştırma alanına ilişkin çeşitliliğin olmasının yansıra doğal güzelliklerin varlığının ve eşsiz kültürel değerlere sahip olmasının güçlü yön olarak değerlendirildiği altyapı ve temel tesislerdeki eksikliklerin zayıf yön olarak ele alındığı görülmektedir. Yine yapılan başka araştırmalarda da kırsal alanların sunduğu manzaraların ve yeşil alanların güçlü yönler olduğu, planlama, yatırım, bilgilendirme ve tanıtım faaliyetlerinin eksikliklerinin zayıf yönler olarak ön plana çıktığı vurgulanmıştır (Fazelnia \& Hedayati, 2010; Khatoon Abadi \& Rast Ghalam, 2011; Danesh Mehr vd., 2012; Millan vd., 2013)

Gevaş ilçesi, coğrafi konumu, zor kış şartları, yoğun göç vermesi ve ekonomik şartlardan dolayı bugüne kadar büyük gelişme göstermemiştir. Doğal ve kültürel unsurların kaynak olarak kullanıldığı turizm yaklaşımlarından biri olan ve sürdürülebilirlik anlayışına sahip turizm etkinliklerinden bir tanesi olan kırsal turizm etkinlikleri kapsamında, sahip olduğu değerler düşünüldüğünde Gevaş ilçesi, Van ilinin turizm dokusuyla uyumlu bir kırsal turizm potansiyeline sahip önemli bir turizm cazibe noktası olabilecek niteliktedir. İlçede yapılabilecek kırsal turizm faaliyetleri arasında dini yapıları ziyaret etme etkinlikleri, suya dayalı etkinlikler, festival ve şenlikler, doğa yürüyüşü, kamp-karavan ile konaklama ve ilçeyi tanıma, yaban hayatı gözlemi, dağ tırmanışı ve yamaç paraşütü, kuş-kelebek gözlemciliği yer almaktadır. Gevaş’ta; kırsal turizm faaliyetlerini geliştirmek, bütünleştirmek, çeşitlendirmek, alanlarının yanlış alan kullanımları ile kaybedilmesini önlemek, alanı içerisindeki yapıların restorasyonlarının gerçekleştirilmesi imkânını oluşturmak için turizm yatırımlarının desteklenmesi gerekmektedir. Bu destekleme sayesinde doğal ve kültürel kaynakları ile dikkat çekici diğer alanlarda olduğu gibi ilçede, doğal, kültürel ve tarihi peyzaj değerlerinin korunarak gelecek kuşaklara aktarılması amacıyla eğitimi ve bilinçlendirilme çalışmalarının önceliklendirilmesi, sorumlu ve ilgili kuruluşların katılımı ve desteğiyle kırsal turizme yönelik planlama çalışmalarının en kısa sürede yapılması, Doğal ve kültürel zenginliklere ait veri bankasının oluşturulması, tanıtım ve markalaştırma çalışmalarına önem verilmesi ile ulusal uluslararası ölçekte tanınırlığı ve destinasyonların doğru yönlendirilmesinde-yönetilmesinde başarıyı artıracaktır.

Kırsal turizm, kırsal yerlerde insanların dinlenme eğlenme ve boş zamanların geçirme gibi amaçlar için ayrılmış ve düzenlenmiş tüm alanların görünümüdür. Kamp ve piknik alanları, plaj, otel ve köy evleri kırsal turizm içine girmektedir. $\mathrm{Bu}$ alanların bilinçli bir planlama ile doğa ile bütünlük oluşturmaları gerekmektedir.

Sonuç olarak, ilçede doğaya müdahaleyi içermeyen ve doğal kaynakları bilinçli bir şekilde kullanmayı öngörebilen etkinlik ve aktiviteleri içeren en uygun turizm çeşitlerinden olan "kırsal turizm" anlayışına yönelik politikalar, stratejiler ve planlamalar geliştirilmelidir.

Destek ve Teşekkür Beyanı (Bu çalışma Artvin Çoruh Üniversitesi Fen Bilimleri Enstitüsü Peyzaj Mimarlı̆̆ Anabilim Dalında yapılan "Van İli Gevaş İlçesinin Kırsal Turizm Potansiyelinin Değerlendirilmesi” isimli yüksek lisans tez çalışmasından üretilmiştir.)

Çatışma Beyanı (Yazarlar arasında herhangi bir çıkar çatışması bulunmamaktadır.)

\section{KAYNAKLAR}

Ahipaşaoğlu, S. \& Çeltek, E. (2006). Sürdürülebilir kırsal turizm, Gazi Kitapevi.

Akşit, S. (2007). Doğal ortam duyarlılı̆̆ı açısından sürdürülebilir turizm. Erciyes Üniversitesi Sosyal Bilimler Enstitüsü Dergisi, 1(23), 441-460.

Alaeddinoğlu, F. (2006). Van il'inin turizm potansiyelinin belirlenmesi ve planlamaya yönelik öneriler. (Yayınlanmamış Yüksek Lisans Tezi). Ankara Üniversitesi, Sosyal Bilimler Enstitüsü.

Avcikurt, C. Alper, B. \& Geyik, S. (2009). Education and training of tourist guides in Turkey. Management and Education Academic Journal, 5(1), 57-63. 
Balcı, S., Dağlar, H., Kara, M. \& Avcı, Ö. (2003). Çankırı'nın alternatif turizm potansiyeli. Türkiye 'nin Alternatif Turizm Potansiyeli ve Güncel Sorunları Konferansı.

Barutçugil, İ. S. (1982). Turizm işletmeciliği. Uludağ Üniversitesi İktisadi ve İdari Bilimler Fakültesi Yayınları.

Baş, G. \& Gül, M. (2018). Gevaş dilmetaş köyü mezarlığı ve mezar taşları. Yüzüncü Yıl Üniversitesi Sosyal Bilimler Enstitüsü Dergisi, 39, 323-348.

Bingöl, Ö. (2004). Deveboynu Yarımadası ve Çevresi (Gevaş-Van) Florası (Yayınlanmamış Yüksek Lisans Tezi). Yüzüncü Y1l Üniversitesi, Fen Bilimleri Enstitüsü.

Çiftçi, Y., Işık, Alkevli M.A. \& Yeşilova, Ç. (2008). Van Gölü Havzasının Çevre Jeolojisi. Jeoloji Mühendisliği Dergisi, 32(2), 45-77.

Danesh Mehr, H., Safari, V. \& Karimi, A. R. (2012). Assessing the role of ecotourism and its effects on development of rural kazemiyeh et al. 12 areas using SWOT analysis. J. Rural Res., 3(11), 215-240.

Dinçer-Şen, S. (2010). Turizmin çevresel etkileri ve bir çözüm olarak ekoturizm (Yayınlanmamış Yüksek lisans Tezi). Mersin Üniversitesi, Sosyal Bilimler Enstitüsü.

Dowling, R.K. \& Fennel, D.A. (2003). Ecotourism planning and policy. CABI Publishing.

Durmuş, A. \& Adıgüzel Ö. (2014). Van ilinin ornito-turizm (kuş turizmi) potansiyeline sahip sulak alanları. Yüzüncü Yıl Üniversitesi, Van Turizmi Geleceğini Arıyor Çalıştayı.

Erdoğan, N. (2005). Sürdürülebilirlik açısından Türkiye'de ekoturizm gerçeği. Ekoloji Magazin-Doğa, Çevre ve Kültür Dergisi, 6, 36-41.

Nasilbiryer.net, (2019). Van Gevaş ilçesi tarihi. Erişim Tarihi: 01.07.2019, http://nasilbiryer.net/il/van/gevas-ilcesitarihi-cografyasi-turizm-foto-galeri-video-tanitim-van

Arkeolojikhaber.com, (2019). Van tarihi eser envanteri. ErişimTarihi: 05.07.2019, https://www.arkeolo jikhaber.com/haber-van-tarihi-eser-envanteri-940

Fabac, R. \& Zver, I. (2011). Applying the modified SWOT-AHP method to the tourism of Gornje Međimurje. Tourism and Hospitality Management, 17(2), 201-215.

Fazelnia G. \& Hedayati S. 2010. Appropriate strategies for tourism development in zaribar lake. J. of Geograph. Dev., $19,145-170$

Gürlek, T. B. (2002). SWOT analizi. Türkiye Bilimsel ve Teknik Araştırma Kurumu.

Hunter, C. \& Green, H. (1995). Tourism and the environment: A sustainable relationship. Routledge.

Kahraman, N. \& Türkay, O. (2004). Turizm ve çevre. Detay Yayıncılık.

Kazemiyeh, F., Sadighi, H. \& Chizari, M. (2018). Investigation of rural tourism in East Azarbaijan province of Iran utilizing SWOT model and Delphi technique. J. Agr. Sci. Tech.,18, 1-13.

Khatoon Abadi, A. \& Rast Ghalam, M. (2011). Assessment of four pillars of rural tourism using SWOT Analysis: case study in Targeted Villages of Chahar Mahal va Bakhtiari Province. J. Econ. Agri. Dev., 25(3), 330-338.

Mahmoudi, B., Haghsetan, A. \& Maleki, R. (2011). Investigation of obstacles and strategies of rural tourism development using SWOT Matrix. Journal of Sustainable Development, 4(2), 136.

Millan, G., Amador, L.and Arjona, J. (2013). Sustainable rural tourism in Andalusia: A SWOT Analysis. Int. J. JAdv. Manage. Econ., 2, 123-136.

Orhan, T. (2008). Uzundere ilçesi ve yakın çevresinin ekoturizm potansiyelinin belirlenmesi ve sınıflandırılması (Yayınlanmamış Yüksek Lisans Tezi). Atatürk Üniversitesi, Fen Bilimleri Enstitüsü.

Polat, A. T. \& Önder, S. (2006). Karapınar ilçesi ve yakın çevresi peyzaj özelliklerinin ekoturizm kullanımları yönünden değerlendirilmesi üzerine bir araştırma. Selçuk Üniversitesi Ziraat Fakültesi Dergisi 20(40), 53-64.

Sayyed, M. R. G., Mansoori Moghaddam, S. \& Jaybhaye, R. G. (2013). SWOT analysis of tandooreh national park (ne Iran) for sustainable ecotourism. J. Proceed. Int. Acad. Ecol. Environ. Sci., 3(4), 296-305.

Seryasat, R. M., Hajari, B., Karimian, T. \& Hajilo, M. (2013). Rural tourism development strategies using SWOT Analysis: case study. Life Science Journal, 10(4), 395-403.

Surat, H. (2011). Yusufeli ve çevresinde analitik hiyerarşi süreci kullanılarak ekoturizm planlaması (Yayınlanmamış Doktora Tezi). Atatürk Üniversitesi Fen bilimleri Enstitüsü, Peyzaj Mimarlığı Anabilim Dalı. 
Surat, H., Yılmaz, H. \& Surat, B. (2015). Yusufeli ve yakın çevresinin ekoturizm kullanım potansiyeli üzerine bir araştırma. Doğu Coğrafya Dergisi, 20(34), 61-88. DOI: 10,17295/dcd.16802

Toskay, T. (1989). Turizm Olayına Genel Yaklaşım. Der Yayınları.

Uçkun, C.G. \& Türkay, O. (2004). Alternatif turizm türlerinin sürdürülebilirliği. Türkiye’nin Alternatif Turizm Potansiyeli ve Güncel Sorunlart Konferanst.

Uçkun, C.G. \& Özer, K.O. (2003). Türkiye de sürdürebilir turizmin sağlanmasında turizm bakanlığının rolü. Türkiye'nin Alternatif Turizm Potansiyeli Güncel Sorunlar Konferans

Yeşiltaş, M. \& Öztürk, İ. (2008). Bölgesel kalkınma çerçevesinde alternatif turizm faaliyetlerine yönelik bir değerlendirme: Sivas örneği. C.Ü. İktisadi ve İdari Bilimler Dergisi, 9(1), 1-18.

Yücel, C. (2002). Turizmde yükselen değer: Ekoturizm. TÜRSAB Ar-Ge Departmanı.

Weaver, D. \& Opperman, M. (2000). Tourism Management. John Wiley \& Sons.

Zhang, X. (2012). Research on the development strategies of rural tourism in suzhou based on SWOT analysis. Energy Procedia, 16, 1295-1299. 